\title{
So You Think You Know Young Adult Literature
}

\author{
James M. Brewbaker
}

Our literature is rich in memorable first sentences

"Call me Ishmael."

"It was the best of times, it was the worst of times, it was the age of wisdom, it was the age of foolishness. ..." And so on. Dickens' muchquoted first sentence, by the way, goes on and on for better than a hundred words and fifteen independent clauses-enough, on the one hand, to make purists turn somersaults in their graves and, on the other, to make me smile subversively.

Some memorable openings are more contemporary.

"If you really want to hear about it, the first thing you'll probably want to know is where I was born, and what my lousy childhood was like, and how my parents were occupied and all before they had me, and all that David Copperfield kind of crap, but I don't feel like going into it, if you want to know the truth."

Other major works feature first sentences that reverberate in a reader's mind but that don't quite ring bells either. These sentences, once their sources are revealed, may cause a reader to mutter, "Oh, sure. That figures. I could've guessed it if I'd had a little time to think about it." Take the following, for example.

"Buck Mulligan came from the stairhead, bearing a bowl of lather on which a mirror and a razor lay crossed." (Joyce, Ulysses)

" $1801-$ I have just returned from a visit to my landlord-the solitary neighbour that I shall be troubled with." (Bronte, Wuthering Heights)

Yet other first sentences just sit there. They're all right as sentences go, mind you, but they don't do much to link title to character, theme, or anything else.
"Through the fence, between the curling flower spaces, I could see them hitting." (Faulkner, The Sound and the Fury)

"Dusk-of a summer night." (Dreiser, $A n$ American Tragedy)

As it is with literature in general, so it goes with adolescent literature in particular, which now offers its own quotable first sentences.

The following quiz, then, is for those who think they know adolescent literature fairly well, well enough to match some significant works from the genre with their famous or not-so-famous first sentences. Indicate your choice by writing the letter of the novel listed below in the space beside the first sentence in the left-hand column. The works are listed in chronological order, and the sentences are alphabetized. Check your answers with the key at the end of the article.

\section{First Sentences}

1. The black-haired sergeant, in the graygreen uniform of the army of Adolph Hitler's Third Reich, sat smoking his pipe on the stone steps of the house.

2. Bud Crayne rounded a curve at fifty and faced into the setting sun.

3. _— "Daddy, I think I'm going crazy."

4. _Don't tell people we've moved to Brooklyn," Tucker Woolf's father always told him.

5. During the summer of 1941, every weekday morning at the top of the tide, McCall Purnell and I would board my skiff and go progging for crab.

6. Ever since I can remember, I had wanted to know about the Land of the 
Golden Mountain, but my mother had never wanted to talk about it.

7. He rode into our valley in the summer of ' 89 .

8 .

He waited on the stoop until twilight, pretending to watch the sun melt into the dirty gray Harlem sky.

9. I I don't know just why I'm telling you all of this.

10. If I hear a person say "Man! That's a blue sky-for sure," I know exact how the sky looks.

11. I I should of been in school that day.

12. It was a dark and stormy night. [Author's note: There may be hope for Snoopy after all.]

13.

"It was Marie Kazinski who asked how to stop a boy if he wants to go all the way," Maggie whispered.

14. I went back to the Devon School not long ago, and found it looking oddly newer than when I was a student there fifteen years before.

15. “Little Man, would you come on?"

16. Newt Winger lay belly-flat at the edge of the cornfield, his brown chin close to the ground, his eyes glued to a hill of busy ants.

17. Now I am thirteen, but when I was a chile, it was hard to be a chile because my block is a tough block and my school is a tough school.

18.

On a morning in mid-April, 1687, the Brigantine Dolphin left the open sea, sailed briskly across the Sound to the wide mouth of the Connecticut River and into Saybrook harbor.

19. The Opportunity Class. That's where the bean picker got put.

20. __ "Sorry Pop," Joe said, "I got something to do."

21. Sybil Davis has a genius I.Q. and has been laid by at least six different guys.

$22 . \quad$ They murdered him.

23. To have a reason to get up in the morning, it is necessary to possess a guiding principle.

24.

When I saw the crowd gathering at the train station, I wondered what President Roosevelt would think.

25.

When I stepped out into the bright sunlight from the darkness of the movie house, I had only two things on my mind: Paul Newman and a ride home.
26.

Yesterday I remember thinking I was the happiest person in the whole earth, in the whole galaxy, in all of God's creation.

\section{Titles and Authors}

A. Seventeenth Summer, by Maureen Daley, 1942.

B. Shane, by Jack Schaefer, 1949.

C. Hot Rod, by Henry Gregor Felson, 1950.

D. The Witch of Blackbird Pond, by Elizabeth George Speare, 1958.

E. A Separate Peace, by John Knowles, 1960.

F. A Patch of Blue, by Elizabeth Kata, 1961.

G. Roosevelt Grady, by Louise Shotwell, 1963.

H. A Wrinkle in Time, by Madeline L'Engle, 1963.

I. The Learning Tree, by Gordon Parks, 1963.

J. The Outsiders, by S. E. Hinton, 1967.

K. The Contender, by Robert M. Lipsyte, 1967.

L. His Enemy, His Friend, by John R. Tunis, 1967.

M. Lisa, Bright and Dark, by John Neufeld, 1969.

N. My Darling, My Hamburger, by Paul Zindel, 1969.

O. Go Ask Alice, author anonymous, 1971.

P. Teacup Full of Roses, by Sharon Bell Mathis, 1972.

Q. Dinky Hocker Shoots Smack!, by M. E. Kerr, 1972.

R. A Hero Ain't Nothin' But a Sandwich, by Alice Childress, 1973.

S. A Day No Pigs Would Die, by Robert Newton Peck, 1973.

T. Summer of My German Soldier, by Bette Greene, 1973.

U. The Chocolate War, by Robert Cormier, 1974.

V. Forever. . . , by Judy Blume, 1975.

W. Dragonwings, by Laurence Yep, 1975.

X. Ordinary People, by Judith Guest, 1976.

Y. Roll of Thunder, Hear My Cry, by Mildred D. Taylor, 1976.

Z. Jacob Have I Loved, by Katherine Paterson, 1980.

Key: 1. L, 2. C, 3. M, 4. Q, 5. Z, 6. W, 7. B, 8. K, 9. A, 10. F, 11. S, 12. H, 13. N, 14. E, 15. Y, 16. I, 17. R, 18. D, 19. G, 20. P, 21. V, 22. U, 23. X, 24. T, 25. J, 26. O

James M. Brewbaker teaches at Columbus College, Georgia. 